\title{
Correction to: Analyzing ipsative data in psychological research
}

\section{Wai Chan ${ }^{1}$}

Published online: 13 February 2021

(c) The Author(s) 2021

\section{Correction to: Behaviormetrika Vol. 30. No. 1.2003.99-121 https://doi.org/10.2333/bhmk.30.99}

The article Some Mathematical Concepts of the Analytic Hierarchy Process, written by Thomas L. Saaty, was originally published Online First without Open Access. After publication in volume 30, issue 1, page 99-121 the author decided to opt for Open Choice and to make the article an Open Access publication. Therefore, the copyright of the article has been changed to (C) The Author(s) 2021 and the article is forthwith distributed under the terms of the Creative Commons Attribution 4.0 International License (https://creativecommons.org/licenses/by/4.0/), which permits use, sharing, adaptation, distribution and reproduction in any medium or format, as long as you give appropriate credit to the original author(s) and the source, provide a link to the Creative Commons license, and indicate if changes were made.

The original article has been updated.

Publisher's Note Springer Nature remains neutral with regard to jurisdictional claims in published maps and institutional affiliations.

The original article can be found online at https://doi.org/10.2333/bhmk.30.99.

Wai Chan

wchan@psy.cuhk.edu.hk

1 Department of Psychology, The Chinese University of Hong Kong, Shatin, Hong Kong 